Revue bibliographique pour le domaine irano-aryen

\title{
Matthew Canepa. « Inscriptions, Royal spaces and Iranian identity: epigraphic practices in Persia and the ancient Iranian world »
}

\section{Olivia Ramble}

\author{
(2) OpenEdition \\ Journals \\ Édition électronique \\ URL : http://journals.openedition.org/abstractairanica/44163 \\ DOI : 10.4000/abstractairanica.44163 \\ ISBN : 1961-960X \\ ISSN : 1961-960X \\ Éditeur : \\ CNRS (UMR 7528 Mondes iraniens et indiens), Éditions de l'IFRI
}

\section{Référence électronique}

Olivia Ramble, « Matthew Canepa. «Inscriptions, Royal spaces and Iranian identity: epigraphic practices in Persia and the ancient Iranian world » », Abstracta Iranica [En ligne], Volume 37-38-39 2018, document 5, mis en ligne le 30 décembre 2018, consulté le 28 septembre 2020. URL : http:// journals.openedition.org/abstractairanica/44163; DOI : https://doi.org/10.4000/abstractairanica. 44163

Ce document a été généré automatiquement le 28 septembre 2020.

Tous droits réservés 


\title{
Matthew Canepa. « Inscriptions, Royal spaces and Iranian identity: epigraphic practices in Persia and the ancient Iranian world »
}

\author{
Olivia Ramble
}

\section{RÉFÉRENCE}

Matthew Canepa. « Inscriptions, Royal spaces and Iranian identity: epigraphic practices in Persia and the ancient Iranian world » in A. Eastmon (ed.). Viewing Inscriptions in the Late Antique and Medieval World. New York: Cambridge University Press, 2015, p. 10-35.

L'A. propose un aperçu historique des pratiques épigraphiques de l'Iran ancien depuis les Achéménides à l'avènement de l'Islam. Au-delà de leur contenu textuel propre et de leur vocation élémentaire à préserver et diffuser un texte, l'A. considère le rôle majeur des inscriptions monumentales, au fil des siècles et des dynasties (des langues et des écritures), dans l'articulation et la délimitation de l'espace royal et cultuel, et dans les rapports de négociation avec les empires rivaux et passés. Comme les bas-reliefs, elles ont été des acteurs visuels et de véritables "technologies of memory" et instruments de pouvoir. L'A. note aussi une évolution dans le principe de visibilité/lisibilité, entre la première inscription de Darius à Bīsōtūn, non lisible depuis le sol, et les inscriptions sassanides de Naqš-e Rostam, placées à hauteur des yeux - une influence de la tradition épigraphique grecque. Une influence des monogrammes pehlevis, entre écriture et ornement architectural, sur la calligraphie et l'art islamiques est envisagée. En somme, une étude novatrice quant à sa prise en compte des inscriptions rupestres de l'Iran ancien dans leur ensemble. 


\section{AUTEURS}

OLIVIA RAMBLE

Doctorante EPHE, Mondes iranien et indien, Paris 